\title{
Analysis of PDDB Online Implementation Policy (Case study at the Sunggal Branch of the North Sumatra Provincial Education Office)
}

\author{
M. Basir Hasibuan \\ Post Graduate of Universitas Negeri \\ Medan \\ Medan, Indonesia \\ basirhasibuan@rocketmail.com
}

\author{
Wildasyah \\ Lecturer at Universitas Negeri \\ Medan \\ North Sumatra, Indonesia
}

\author{
Din Oloan Sihotang \\ Lecturer at Politeknik IT \& B Medan \\ North Sumatra, Indonesia
}

\begin{abstract}
The purpose of this study was to determine the extent to which the use of resources used related to the implementation process of New Student Admission Policy (PPDB) and To find out the organization related to the implementation of Online New Student Admission (PPDB) policy in Upper Middle School in the Education Agency North Sumatra Province. The method used in this study is a descriptive research method with a qualitative approach. The location of this research was conducted at the North Sumatra Provincial Education Office in Teuku Cik Ditiro No.1 SMAN 1 Sunggal consisting of Student Parents, Students, operators. Data collection techniques are interviews, documentation. Data Analysis Techniques are Data Reduction, Data Presentation, and Conclusion Withdrawal. From the results of the research found in the use of resources in the implementation of new student admissions (PPDB) Online, the education office authorized to implement this policy uses human resources by empowering 9 outside programmers and one from within the education office to design the PPDB Online website system. Empowering the Ministry of Communication and Information. While the problem of organizing is a task of the education office as an organization which is tasked with managing the problem of education in order to improve its services to the community
\end{abstract}

Keywords- new; student; admissions; online; resources

\section{INTRODUCTION}

The development of information and communication technology that is so fast now, realized or not has changed the mindset, culture, perspective and behavior of society. Evidence of this development is, among others, the emergence of computer technology. The existence of computer development has been included in all sectors of human life, especially in the education sector. Technological developments also require the world of education to use it in providing educational services in Indonesia so as not to be left behind by other nations.

According to [1], education in the global era plays a very important and strategic role in preparing human resources who are qualified and competent in their fields, to realize an advanced and competitive society in responding to global challenges.Seeing this, the government which is given the obligation by the state constitution is required to improve the quality of education by continuously providing quality and easily accessible services to the people in realizing the state's goal of educating the nation's lifeAs in the service of new student admissions where the process is often encountered fraudulent practices such as cases of entrusted students, bribery cases bribing and the transparency of services provided. This is what becomes a public complaint every time a new student receives activities.

Given that North Sumatra Province is one of the provinces under the supervision of the Corruption Eradication Commission due to the poor service performance of its government. So the government in this case the KPK made an action plan to improve public services especially in the education sector as well as a way to prevent fraudulent practices of Collusion, Corruption and Nepotism (KKN) in matters of public services. Based on the Republic of Indonesia Government Regulation Number 17 of 2010 concerning the management and implementation of education, specifically article 72 (paragraphs 1 and 2) and article 82 (paragraphs 1 and 2) concerning student acceptance in primary or secondary education units must be objective, transparent, accountable, and not discriminatory. To carry out the mandate of this Act, the KPK made an action plan by implementing an Onlinebased New Student Acceptance (PPDB) policy.

The use of information technology on Student Admission (PPDB) Online is a real step to encourage the creation of good governance in the education sector[2]. PPDB was chosen, because it became the initial input of the education management process carried out by the school. If the input is well managed, it is hoped that the follow-up process will work well. Good governance is oriented on how to achieve goals effectively and efficiently, so that if the implementation of the PPDB Online program runs effectively and efficiently then good governance can be created in the education sector.

\section{LITERATURE REVIEW}

\section{A. Public Policy}

Public policy according to the[2] is whatever the choice of the government to do or not to, mean while the [3] implies that (1) public policy is made by a government body, not a private organization, (2) public policy concerning choices that must be made or not carried out by government agencies. 
Based on the opinions of various experts, it can be concluded that public policy is a series of actions carried out or not carried out by a government that is oriented towards a specific goal in order to solve public problems or in the public interest. The policy to do something is usually contained in the provisions or legislation made by the government so that it has a binding and compelling nature.

\section{B. Characteristics of Policy}

As author [4] presents several characteristics of the policy, namely as follows:

- Every policy prepared must have a purpose. The point is that any policy making should not be made as long as possible, there must be a problem behind a policy making.

- A policy cannot stand alone, separate from other policies that have been prepared beforehand.

- Policies carried out by the government, should not be what the government still wants to do, so that it can provide benefits for policy objectives.

- Policies can be negative or prohibit and can also be directed to implement or advocate.

- The policies prepared must be based on the applicable law, so that they have the authority to force the community to implement the policies implemented

\section{Model of Policy Implementation}

1) Models of Donald Van Meter and Carl Van Horn

There are six variables, according to [5], which affect the performance of public policy implementation. Policy size and objectives Performance of policy implementation can be measured if the success rate is only if the size and objectives of the policy are indeed realistic with socioculture at the level of policy implementers

Resources The success of the policy implementation process depends on the ability to utilize available resources. Humans are the most important resource in determining the success of the implementation process.

Characteristics of Executing Agents The focus of attention on implementing agents includes formal organizations and informal organizations that will be involved in implementing public policies. This is very important because the performance of policy implementation (public) will be very much influenced by the right characteristics and match with the implementing agents.

Attitudes (Dispositions) of Executors The attitude of acceptance or rejection of implementing (agents) will greatly affect the success or failure of the performance of public policy implementation

- Inter-Organizational Communication and Implementing Activities Coordination is a powerful mechanism in the implementation of public policy. The better the coordination of communication between the parties involved in an implementation process, the assumption is that errors will be very small to occur and vice versa.

- Economic, Social and Political Environment. The social, economic and political environment that is not conducive can be the culprit of the failure of policy implementation performance. Therefore, efforts to implement policies must also pay attention to the conduciveness of external environmental conditions

2) George Edwards III model

In his view George III explained that policy implementation is influenced by four factors [6], namely:

a. Communication A success of policy implementation requires that the implementator know what he has to do. Knowing what is the target and goal must be communicated to the target group so that it will reduce deviations in implementation.

b. Resources Resources are very important if their implementers lack resources for implementation, implementation will not be effective. Resources can be human and financial resources.

c. Disposition Disposition is the characteristics, character and characteristics possessed by the implementor such as commitment, honesty and democratic attitude. If an implementor has a good disposition then he will directly be able to run the policy well as desired by policy makers.

d. Bureaucratic Structure The organizational structure has a very significant influence on policy implementation. One of the important structural aspects of any organization or government is the procedure

Thus, from the two policy theories above, if implemented with education, education policy is aimed at the welfare of the people who are education customers. Therefore, education services must provide excellent service quality reflected in:

- Transparency, namely services that are open, easy and can be diakes by all parties who need and are provided adequately and easily understood;

- Accountability, namely services that can be accounted for in accordance with the provisions of legislation;

- Conditional, that is service that is in accordance with the conditions and ability of the giver and recipient of the service by adhering to the principles of efficiency and effectiveness;

- Participatory, namely services that can encourage the participation of the community in the implementation of public services that pay attention to the aspirations of the needs, and expectations of the community;

- Equal rights, namely services that do not discriminate are seen from any aspect, especially ethnicity, race, religion, class, social status, etc.; 
- Balance of rights and obligations, namely services that consider aspects of justice between the giver and recipient of public services.

\section{New Student Admission (PPDB) Online}

PPDB Online or New Student Admission is the activity of receiving prospective new students who meet certain requirements through the entry process, using a database system, automatic selection by computer programs and selection results can be accessed at any time online [8]. Online New Student Admission (PPDB) system in North Sumatra includes the levels of education for Senior High Schools / Islamic Senior High Schools (SMA / MA) and Vocational High Schools (SMK). The purpose of implementing PPDB Online [9] are:

- Assist the Education and Culture Office and schools in implementing PPDB

- perfecting the process of implementing PPDB

- Increasing orderly administration and administration of PPDB

- Increasing access in the context of equitable learning opportunities for the community

- Increasing accountability for implementing PPDB

- Improve the quality of PPDB services

- Information for the community is faster, easier and more accurate

With the implementation of PPDB Online, several benefits of PPDB can be obtained, including:

- As a measure of performance standards for Dinas and schools in implementing PPDB

- Increasing accountability, efficiency, effectiveness and transparency in the overall implementation of PPDB

- Ensuring consistency of service to the community from the quality, time and procedure aspects.

The principle of implementing PPDB Online is:

a) Objective, meaning that the acceptance of new students must meet the general provisions stipulated in this decision,

b) Transparent, meaning that the implementation of new student admissions is open and can be known by the community in question the parents / guardians of prospective students,

c) Accountable, meaning that the acceptance of new students can be accountable to the community both the procedure and the results,

d) Competitive, meaning new student admission is done through selection based on school grades and the value of National Examination (UN), Achievement and Domicile of prospective students [10].

\section{METHODOLOGY}

The method used in this study is a descriptive research method with a qualitative approach. In this study, a researcher will develop concepts and gather facts but will not carry out hypothesis testing. The location of this research was conducted at the North Sumatra Provincial Education Office in Teuku Cik Ditiro No.1, SMAN 1 Sunggal consisting of Student Parents, Students, operators.

Data collection techniques are interviews and documentation. Data Analysis Techniques are data reduction, data presentation and conclusion drawing. The technique of checking the validity of data is triangulation is a research approach that uses a combination of more than one strategy in one study to capture data / information.

\section{RESULTS AND DISCUSSION}

Online New Student Admission Policy (PPDB) The level of high school is based on the direction of the KPK based on the many public complaints to the Ombudsman institution about frauds that often occur when new student admissions such as bribery, entrusted students and school problems superior that only certain people can enter. Therefore the North Sumatra Provincial Government, especially the North Sumatra Provincial Education Office, carries out the policies included in the KPK's action plan, namely implementing new student admissions with the Online system.

Online Student Admission (PPDB) is a 100\% websitebased system and this is the first time this has been done in the province of North Sumatra as well as Indonesia because PPDB Online has only been carried out at other districts in the region, this is what makes PPDB Online entered as one of the breakthrough programs of the North Sumatra government PPDB Online was implemented because in the implementation of admissions, students in North Sumatra province had experienced various problems, namely:

- Lack of transparency and accountability in implementing PPDB

- Inefficient implementation of PPDB

- Low quality of education services

- Availability of invalid educational data

\section{A. Location of Decision Making}

The decision-making process of the Online New Student Admission (PPDB) policy at the High School Level starts from the Action Plan of the Corruption Eradication Commission (KPK) in which North Sumatra Province is one of the Provinces which received special attention from the KPK.

Given that the public service sector in North Sumatra is considered to have poor service, especially in the education sector, the Corruption Eradication Commission (KPK) has made an action plan to improve the service. The North Sumatra Provincial Government through the Education Agency responded to the action plan by implementing the PPDB Online policy for the Upper Middle School level in North Sumatra's high school / Vocational High School which was fully supported by the governor of North Sumatra by making it a flagship program in North Sumatra. 


\section{B. Program Implementer}

In implementing a policy must be supported by the presence of policy implementers who have the competence and capacity for the success of the policy. Online Student Admission Policy (PPDB) is carried out by the North Sumatra education office and in its implementation the service establishes an executive committee tasked with the success of this policy.

1) Resources

In this Online Student Admission (PPDB) policy, the human resources used by the North Sumatra provincial education office are still inadequate, because the education office uses human resources with a total of 10 people, of which 10 are 9 experts programs from outside the education office and 1 person from the service education,

2) Policy and Organizing.-p

In a policy it is necessary to take into account the power or power, interests, and strategies used by the actors involved to launch a policy implementation.

- Power.

- Policy

- Organizing.

\section{Characteristics of Policy Taking Institutions}

Characteristics of institutions or what is known as organizational culture is a characteristic that is highly respected by the organization in achieving its objectives. The Online Student Admission Policy (PPDB) gets very full support from the government of North Sumatra, even PPDB Online is included in the top 5 programs of the Government of North Sumatra

\section{CONCLUSION}

Implementation of new student admission policies (PPDB) Online high school level in the North Sumatra provincial education office in general has been going well, seen from the 2 important variables of the process of implementing the new Student Admission (PPDB) policy as stated by Van Meter and Van Horn, namely:

- Resource.

In implementing Online Student Admission (PPDB) Online, the education office authorized to implement this policy uses human resources by empowering 9 programmers from outside the office and one from within the education office to design the PPDB Online website system, empowering the Ministry of Communication and Informatics. This proves that the education office is very serious in its implementation so that it presents professional experts, aside from human resources
In information resources there are still many people who do not get socialization or information about the implementation of PPDB Online which results in people lacking in information and having the effort to use old ways to manage so that they can graduate. This is what hinders the Implementation of PPDB Online.

- Organizing

The education office as an organization tasked with managing education problems is guided to be able to improve its services so far. Responding to the demands of the community, the education office redesigned its organization with the aim of creating an effective work system. One of the determining factors when designing an organization is the factors related to the situation faced by the organization, such as strategy, technology, and tasks.

\section{ACKNOWLEDGMENT}

This paper and the research behind it would not have been possible without the exceptional support of my lecturer, Eka Daryanto and Wildansyah Lubis. Their enthusiasm, knowledge and exacting attention to detail have been an inspiration and kept my work on to finish my study in Universtas Negeri Medan. And to AISTEEL Committee and Riviewers to accept this paper published.

\section{REFERENCES}

[1] Agustino. 2016. Dasar-dasar Kebiajakan Publik. Bandung: Alfabeta.

[2] Subarsono, 2005. Analisis Kebijakan Publik. Yogyakarta: Pustaka pelajar

[3] Jurnal : Andreas Wintoko. Implementasi Pelayanan Publik Program Penerimaan Peserta Didik Baru Melalui Sistem Online (Studi di SMAN 1 Banyuwangi dan SMAN 1 Singojuruh Kabupaten Banyuwangi). Jurnal ilmu administrasi publik Vol 4, No 4 (2016).

[4] Jurnal Teknika Vol 6 No 1, Tahun 2014, Sistem Penerimaan Peserta Didik Baru Berbasis Web (Online) Di SMK Muhammadiyah 7 Kedungpring Lamongan (Miftahus Sholihin, Siti Mujilahwati)

[5] Van Meter, Donal dan Van Horn, Carl E. 1975. The Policy Implementation Process Conceptual Frame Work. Journal Administration and Society.

[6] Edwards III, George C. 1980. Implementing Public Policy. Washington: Cogressional Quaerterly Inc

7] Yusuf Farlin, Jamal Maulana "Kajian Kepuasan Pengguna Informas Penerimaan Peserta Didik Baru (PPDB) online”. Jurnal on computer and imformation Technology. Vol 2 November 2017.

[8] Setiawan Dedi. 2016. Implementasi kebijakan penerimaan peserta didik baru sekolah menengah atas sistem real time online (RTO) di kabupaten Bnatul tahun pelajaran 2015/2016. Skripsi. Program sarjana Administrasi Pendidikan. Universitas Negeri Yogyakarta. Yogyakarta.

[9] Peraturan pemerintah RI Nomor 17 Tahun 2010 pasal 74 (ayat 1 dan 2) dan pasal 82 (ayat 1 dan 2) tentang penerimaan peserta didik pada satuan pendidikan dasar/menengah

[10] https://medan.tribunnews.com/2019/03/29/pengumuman-ppdbwebsite-disdikoverload diakses pada talgal 29 Maret 2019 pukul 19.45 